\title{
Mid-term changes in the physiognomy of plant communities and functional plant groups define successional pathways of mountain vegetation in the province of Córdoba (Argentina)
}

\author{
Marcos Sebastián Karlin ${ }^{1,2^{*}}$, Sebastián Abel Arnulphi ${ }^{1,2}$, \\ Javier Rodolfo Bernasconi Salazar ${ }^{2}$
}

\author{
${ }^{1}$ Universidad Nacional de Córdoba - Facultad de Ciencias Agropecuarias, \\ Ing. Agr. Félix Aldo Marrone N ${ }^{0} 746$, Ciudad Universitaria, Córdoba, Argentina \\ ${ }^{2}$ Asociación Civil El Cuenco - Equipo Ambiental, Manuel Abad e Illana N ${ }^{\circ} 2337$, \\ Córdoba, Argentina
}

\begin{abstract}
Karlin, M.S., Arnulphi, S.A., Bernasconi Salazar, J.R., 2021. Mid-term changes in the physiognomy of plant communities and functional plant groups define successional pathways of mountain vegetation in the province of Córdoba (Argentina). Folia Oecologica, 48 (1): 9-24.

To identify restoration strategies over degraded semi-natural plant communities, successional pathways and their local controls should be identified. The objective of this work is to quantify the changes in the physiognomy and functional groups of plant communities in the Sierras Chicas of Córdoba along seven years. Lyapunov coefficients were calculated and arranged in two-phase diagrams, identifying different successional pathways over two soil categories and six plant communities. Du Rietz's life forms were identified defining several plant functional groups. Results showed two successional pathways in the field of azonal soils and three in the field of intrazonal soils. Rainfall, extent of human-caused disturbances, and plant interactions are the leading causes explaining the changes in the structure of the plant communities. Fire and overgrazing retract the successions by altering the cover of plant communities and their functional groups.
\end{abstract}

\section{Keywords}

azonal soils, forests, grasslands, intrazonal soils, plant community, woodlands

\section{Introduction}

The ability of the ecosystems to provide specific goods and services depends on the specific properties of the ecosystem and the role of organisms, or groups of organisms, in control of such properties (DE BELLO et al., 2010). In terrestrial ecosystems, plants are the key organisms controlling the ecosystem's functionality.

Soil (KARDol et al., 2006), climate (CoREnblit et al., 2009; Nuche and Alados, 2018), plant-specific competition (KARLIN et al., 2016; ULRICH et al., 2019) and human activities (DAVIDSON, 1993; CASTOLDI et al., 2013) are specific and direct controls over plant populations. Logging, wildfires, overgrazing, contamination, and soil depletion are some of the most common humaninduced disturbances. They often define the direction of successional pathways of plant communities. Identifying restoration strategies over degraded semi-natural plant communities is essential for evaluating such successional pathways, its local controls, and the relative condition with respect to other communities.

*Corresponding author: 
Reconstruction of plant successions is usually challenging because it may be difficult to locate or discriminate different kinds of plant ensembles within specific successional pathways. Sometimes such ensembles might be part of the same succession, but sometimes, despite that floristic composition is similar in different communities, they might not. One alternative for identifying the successional pathways is to define these as gradual directional changes of phytocoenosis replacement caused by the reaction upon soil development, according to the Clementian original sense (MORAVEC, 1969).

The Clementian lineal deterministic succession has some intrinsic characteristics for the ecological analysis. It allows both short and long term predictions, and it predicts a single pathway after the disturbance (CRAIG et al., 2012). These characteristics make the model simpler and allow setting more practical ecosystemic management protocols.

Some authors have quantified primary and secondary ecological successions by applying thermodynamic indicators such as Lyapunov coefficients. This method was already evaluated in other ecological contexts such as thorny woodlands in plains (KARLIN et al., 2013) and saline areas (KARLIN et al., 2011). These are calculated as the Euclidean distance of a specific plant community, in terms of relative cover of functional plant groups, and with respect to a reference condition usually defined as a steady-state community within the succession. Lyapunov coefficients are analogous to some dissimilarity indexes.

The plant communities in the mountain areas of Córdoba (Argentina) are severely affected by disturbances such as logging, fire events, grazing, and invasion of alien forest species, among other (KARLIN et al., 2014). They define several states and transitions (BERNASCONI et al., 2015) that might help to build the successional pathways of plant communities. To date, there are few experimental studies about successional pathways of plant communities for the Sierras Chicas in Córdoba. Most of the studies found were focused on post-fire recovery and usually studied short-term periods (TORRES et al., 2014; KARLIN et al., 2016).

This paper examines the changes that have occurred in the physiognomy and functional groups of plant communities in a representative sector of the Sierras Chicas (Argentina) over a seven-year period. Methodologies based on plant community cover and their functional groups, which have proven to be useful in the evaluation of other terrestrial ecosystems, were applied for the identification of different successional pathways and the quantification of disturbances. The identification of the successional pathways and the relationships between plant functional groups may allow the formulation of management protocols for the conservation of plant and soil resources in natural and semi-natural areas.

The hypothesis is that plant communities such as grasslands, Vachellia spp. woodlands and Schinopsis lorentzii (Griseb.) Engl. forests, on the one hand, and riparian grasslands, Sebastiania commersioniana (Baill.) L.B. Sm. \& Downs and Lithraea molleoides (Vell.) Engl. forests, on the other hand, are part of two different successional pathways.
The objective of this work is to quantify the changes in the physiognomy and functional groups of plant communities in the Sierras Chicas of Córdoba by identifying different successional pathways.

\section{Materials and methods}

Plant surveys were performed during spring (OctoberDecember) of the years 2012, 2017 and 2019 in the mountain areas of the Natural Reserve of the Defence La Calera, near Córdoba, Argentina. This study was performed within the area between $31^{\circ} 27^{\prime} 37^{\prime \prime} \mathrm{S}$ and $31^{\circ} 21^{\prime} 07^{\prime \prime} \mathrm{S}$ latitude and between $64^{\circ} 27^{\prime} 50^{\prime \prime} \mathrm{W}$ and $64^{\circ} 20^{\prime} 30^{\prime \prime}$ W longitude, covering about $87 \mathrm{~km}^{2}$. The area was declared as a natural reserve in the year 2009; nevertheless, human activities such as cattle raising, continue. The study site was historically occupied by large livestock herds; however, during 2018-2019, livestock was drastically reduced to few animals grazing extensive rangelands. Fire events occur periodically depending on climatic conditions and grass accumulation. Invasive alien woody species expands yearly, especially in humid valleys. In the studied area, the average annual rainfall is $800 \mathrm{~mm}$ and occur most in the warm season.

The zonation for the plant surveying was based on a local floristic map (KARLIN et al., 2014) and a soil map (KARLIN et al., 2018). Two soil categories, azonal and intrazonal soils (BALDWIN et al., 1938), were identified. The first was represented by Lithic Ustorthents and the second by an organic phase of a Lithic Ustorthents and Typic Ustifluvents. Within the area of azonal soils, three plant communities were identified: Schinopsis lorentzii forests (Sc), Vachellia spp. woodlands (V) and grasslands/mixed woodlands (G/MW). Within the area of intrazonal soils, three plant communities were identified: Sebastiania commersioniana forests (S), Lithraea molleoides forests (Lm) and riparian grasslands (R). The plant categories were assigned according to the occurrence of the most abundant populations or functional plant groups. Phytocenological records (see Appendix 1 and 2) were made on each randomly selected plot (24 plots from the area of azonal soils; 11 plots from the area of intrazonal soils) repeatedly each year (2012, 2017 and 2019) according to the Braun-Blanquet phytocenological method (Braun-Blanquet, 1979). Fire affected plots differed according to the surveyed year and the location of fire events: one case in 2012, six cases in 2017, and none in 2019. Fire affected plots only occurred in the Sc, V, and G/MW categories. The overgrazed plots identified as areas with less than $20 \%$ of graminoids cover were 14 in 2012 , 12 in 2017, and seven in 2019. All plant categories showed at least one plot with overgrazing evidence (Fig 1).

In total, 256 species were identified. Values of coverdominance were transformed into per cent cover values based on the midpoint of each value on the coverabundance scale (WIKUm and SHANHOLTZER, 1978).

For each plot, the relative covers of the plant species were summed according to plant categories modified from Du Rietz`s life form classification (Du RIETZ, 1931): 


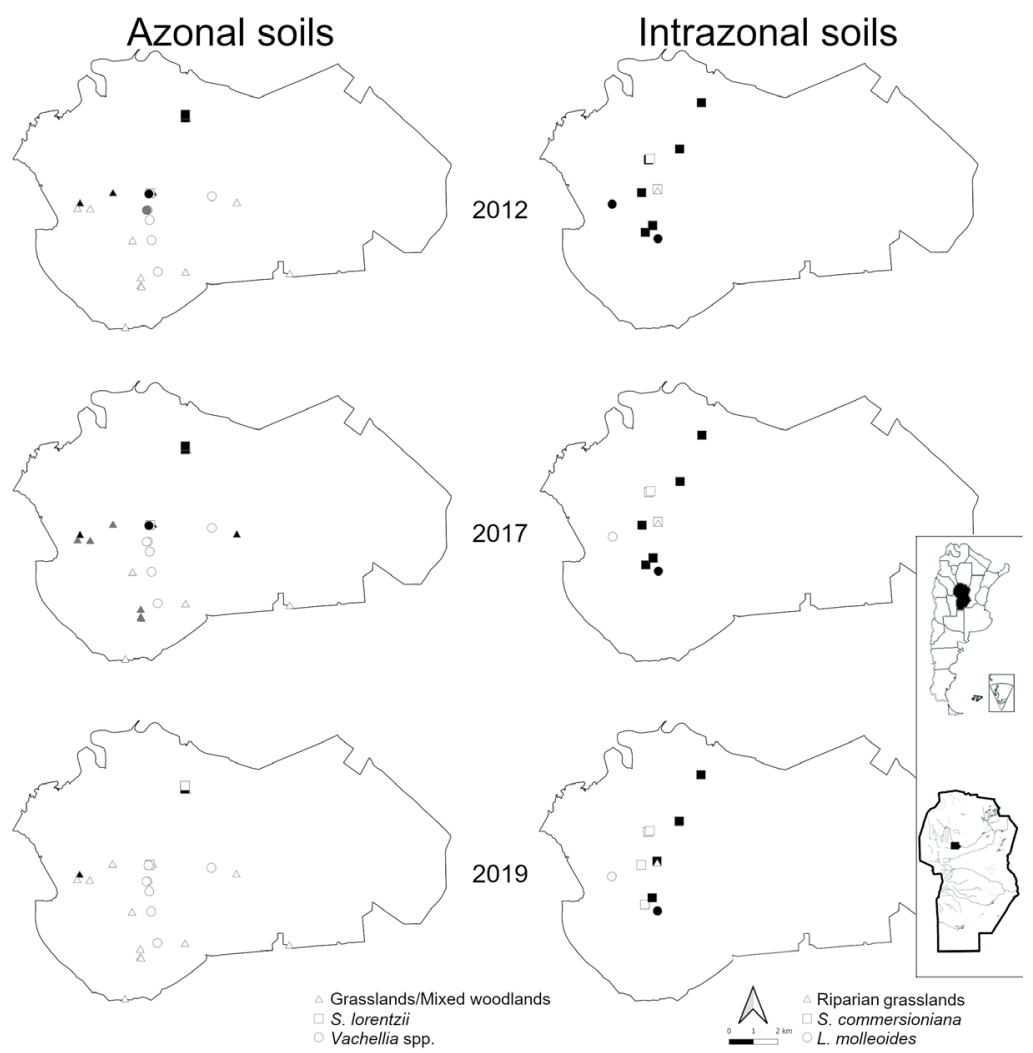

Fig 1. Relative location of the studied plots and disturbance history, within the limits of the Natural Reserve of the Defence La Calera.

In the area of azonal soils (left); $\Delta$ : grasslands/mixed woodlands; $\square$ : S. lorentzii forests; $\circ$ : Vachellia spp. woodlands. In the area of intrazonal soils (right); $\Delta$ : riparian grasslands; $\square$ : S. commersioniana forests; $\bigcirc$ : L. molleoides forests. In white, undisturbed plots; in black, plots with overgrazing evidence; in grey, fire-affected plots.

a) Native trees: native woody plants with a distinct main trunk remaining unbranched in its lower part;

b) Alien trees: non-native woody plants with a distinct main trunk remaining unbranched in its lower part;

c) Shrubs: woody plants not developing a distinct main trunk, with the stem branched from its basal part above or below the soil surface;

d) Lianes: woody or herbaceous plants of various heights and various types of ramification, climbing on the trunks and branches of trees, shrubs, rocks, etc.;

e) Half-shrubs: plants with only the lower parts of the (epigeous) stem lignified and perennial, the upper parts annual and herbaceous;

f) Herbaceous dicots: herb plants with two cotyledons;

g) Graminoids: herb plants with one cotyledon;

h) Pteridophytes: vascular plants dispersing spores;

i) Cactoids: succulent plants from the Cactaceae plant family;

j) Epiphytes: plants that grow on other plants but are not parasitic;

k) Parasitic plants: plants that derive some or all of their nutritional requirement from other living plants.

Native and alien tree species have different water consumptions (ZeBallos et al., 2014) and effects over the soil (KARLIN et al., 2019), while dicots, graminoids, and pteridophytes respond differently according to the availability of soil water (CICUZzA et al., 2013).

Kruskal-Wallis tests, multivariate ANOVA tests, and Pearson's correlation analysis were performed with the statistical software InfoStat (Di RIENzo et al., 2019). Discriminant analysis (Euclidean distance) were performed by analysing the relative cover of each identified life form, discriminated by soil category and clustered by plant community and disturbance category. Two biplots were obtained to evaluate the severity of disturbances and identifying the reference conditions in each soil category.

For the identification of the plant community successional pathways, Lyapunov coefficients were calculated as the Euclidean distance of each plot from a reference condition, measured by the relative cover of each plant community population. The difference between the relative cover of the $i^{\text {th }}$ population in the reference situation, $N_{i}^{*}$, and the current situation (the current size of the $i^{\text {th }}$ population, $N_{i}$ ), is considered as the perturbation of the system (Justus, 2008) from the reference state. The Lyapunov coefficients $(L)$ are therefore calculated according to the following formula (JøRGENSEN and SVIREZHEV, 2004):

$$
L=\left[\sqrt{\sum_{i=1}^{n}\left(N_{i}-N_{i}^{*}\right)^{2}}\right]^{2}, i=1, \ldots, \mathrm{n} .
$$


The reference conditions were selected in each soil category, regarding the history of disturbance shown in the biplots, and by weighting the maximum relative cover of trees and graminoids. A community of S. lorentzii and a community of $S$. commersioniana were selected as reference plant communities for azonal and intrazonal soils, respectively.

The Lyapunov coefficients and the tree cover values were used to plot two-phase diagrams, one for each soil category. In the phase diagrams, Lyapunov coefficients show the dissimilarity of each surveyed plot regarding the reference condition. The tree cover serves as a sort of time dimension, supposing that a plant succession evolves towards a higher tree cover condition. The Lyapunov coefficients are relatively easy-to-calculate indexes; they are based on community dissimilarities, therefore they are more intuitive and suitable to compare with field observations, and can be easily correlated to other variables in order to examine different ecological relations.

Meteorological data were partially collected from an automatic station located within the study area. The obtained data correspond to the period of November 2012 to March 2016, while the rest was collected from the Córdoba Airport at $20 \mathrm{~km}$ from the study area. These additional data were used to adjust and regressed the local data, filling the missing data by using the obtained regression. The precipitation data were used to calculate the annual pluviometry, from July to June of each year. With the local adjusted data, the Standardised Precipitation Indexes (SPI) were calculated according to NARESH KUMAR et al. (2009).

\section{Results}

\section{Standardised Precipitation Indexes}

The SPI distribution is shown in Fig. 2. As can be seen from the figure, 2012 was a dry year, as were 2010/11 and 2008/09. The year 2017 was a dry year, following a three-years wet period; the drought in 2017 created the conditions for a wildfire that affected almost 3,000 ha and six of the 24 plots in the azonal soils. The year 2019 was wet, following a two-years dry period (2017/18 and $2016 / 17)$. The yearly SPI values were $-0.28,-0.37$ and 0.26 for $2011 / 12,2016 / 17$ and $2018 / 19$, respectively.

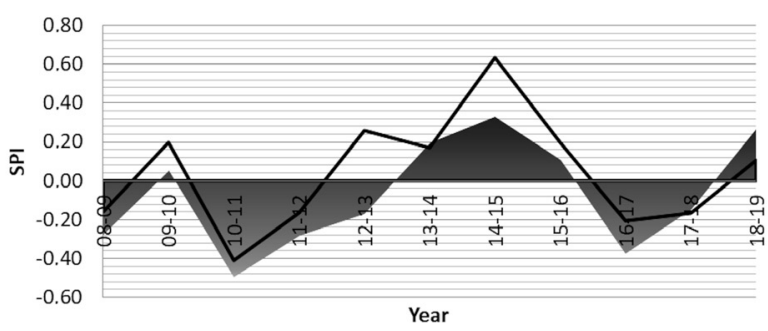

Fig. 2. Standardised Precipitation Indexes (SPI) distribution for the 2008/09-2018/19 period. Local adjusted data; darker color, more humid period; lighter color, drier period. Black line: data from Córdoba Airport.

\section{Changes in the occurrence of functional groups}

Figures 3 and 4 show the distribution of the surveyed plots, according to the relative cover of the functional plant groups. The plots from the area of azonal soils can be seen in Fig. 3, while those from the area of intrazonal soils can be seen in Fig. 4.

The undisturbed plant communities in the area of azonal soils (Fig. 3) showed statistically significant differences $(F=3.52 ; p<0.0001)$ between the studied years. In the drier year of 2012, the relative cover of cactoids and parasitic species was superior to those in 2017 and 2019, while the relative cover of herbaceous dicots was reduced in both years. The year 2017 showed a larger proportion of shrubs and half-shrubs. Half-shrubs, herbaceous dicots and graminoids were the most affected functional groups; half-shrubs (2012: 0.02; 2017: 0.09; 2019: $0.02 ; H=4.43 ; p=0.0977)$ and herbaceous dicots (2012: $0.11 ; 2017: 0.20 ; 2019: 0.20 ; H=5.78 ; p=0.0555$ ) increased their relative cover in the area of azonal soils during 2017 while the opposite trend occurred during drier conditions. Graminoids reduced their relative cover during 2017, and increased them in 2019 (2012: 0.47; 2017: 0.21; 2019: 0.93; $H=23.71 ; p<0.0001)$.

The disturbed plots in the area of azonal soils (Fig. 3 ) were clustered separately from the undisturbed plots. The most important effect of fire and overgrazing was the reduction in the relative cover of graminoids. The centroids of the disturbed plots tend to collapse into a similar reliability ellipse. Pteridophytes showed higher relative cover under disturbed conditions (disturbed: 0.02; undisturbed: $\left.4.9 \cdot 10^{-3} ; H=2.46 ; p=0.0747\right)$.

In the area of intrazonal soils (Fig. 4), undisturbed plant communities also showed significant differences between years $(F=8.74 ; p=0.0241)$. Both half-shrubs (2012: $0.13 ; 2017: 0.02 ; 2019: 0.11 ; H=7.11 ; p=0.0273$ ) and graminoids $(2012: 0.45 ; 2017: 0.27 ; 2019: 0.53 ; H=$ $4.77 ; p=0.0913)$ reduced their relative cover during 2017; herbaceous dicots $(H=3.04 ; p=0.2176)$ and pteridophytes $(H=0.30 ; p=0.8768)$ were seemingly unaffected along the evaluation period.

The disturbed plots in the area of intrazonal soils (Fig. 4), exclusively due to overgrazing, showed a reduction in the relative cover of graminoids. Pteridophytes significantly increased their relative cover in disturbed plots (disturbed: 0.04; undisturbed: 0.02; $H=3.45 ; p=$ $0.0609)$, located in the area of azonal soils.

The relative cover of trees in the reference plots located in the area of both azonal and intrazonal soils were 0.850 and 0.660 , respectively, while those for graminoids were 1.055 and 0.900 , respectively.

Some functional plant groups may be facilitators or competitors of other functional groups. Changes in the cover of functional groups due to soil characteristics or to anthropic disturbances might enhance such relations. In Table 1, Pearson's correlation coefficients are shown for each soil and disturbance category. 


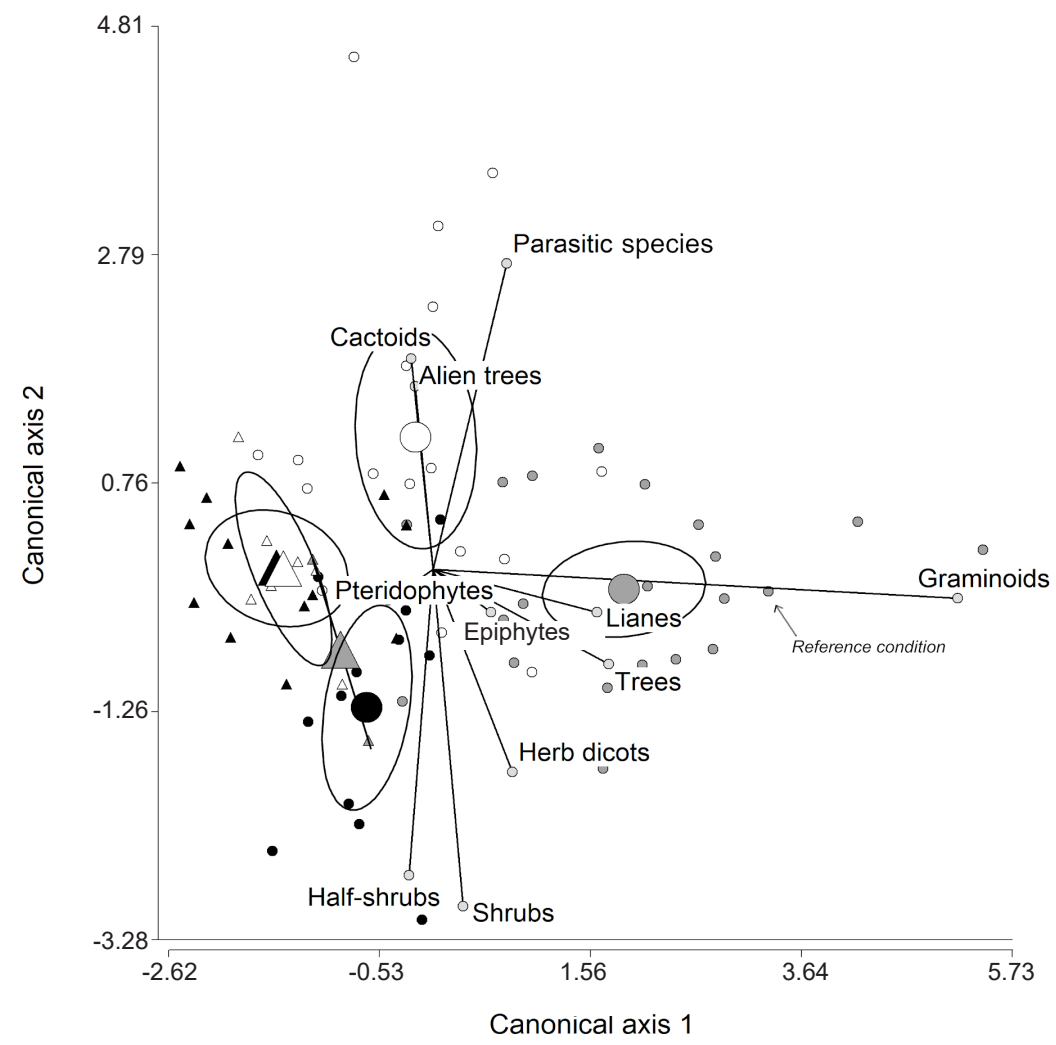

Fig. 3. Biplot of the plant groups in the area of azonal soils.

Triangles: disturbed plots (by overgrazing or fire); circles: undisturbed plots. Small symbols represent individual plots; large symbols represent the centroids of each treatment associated with their confidence ellipses. In white: 2012; in black: 2017;

in gray: 2019.

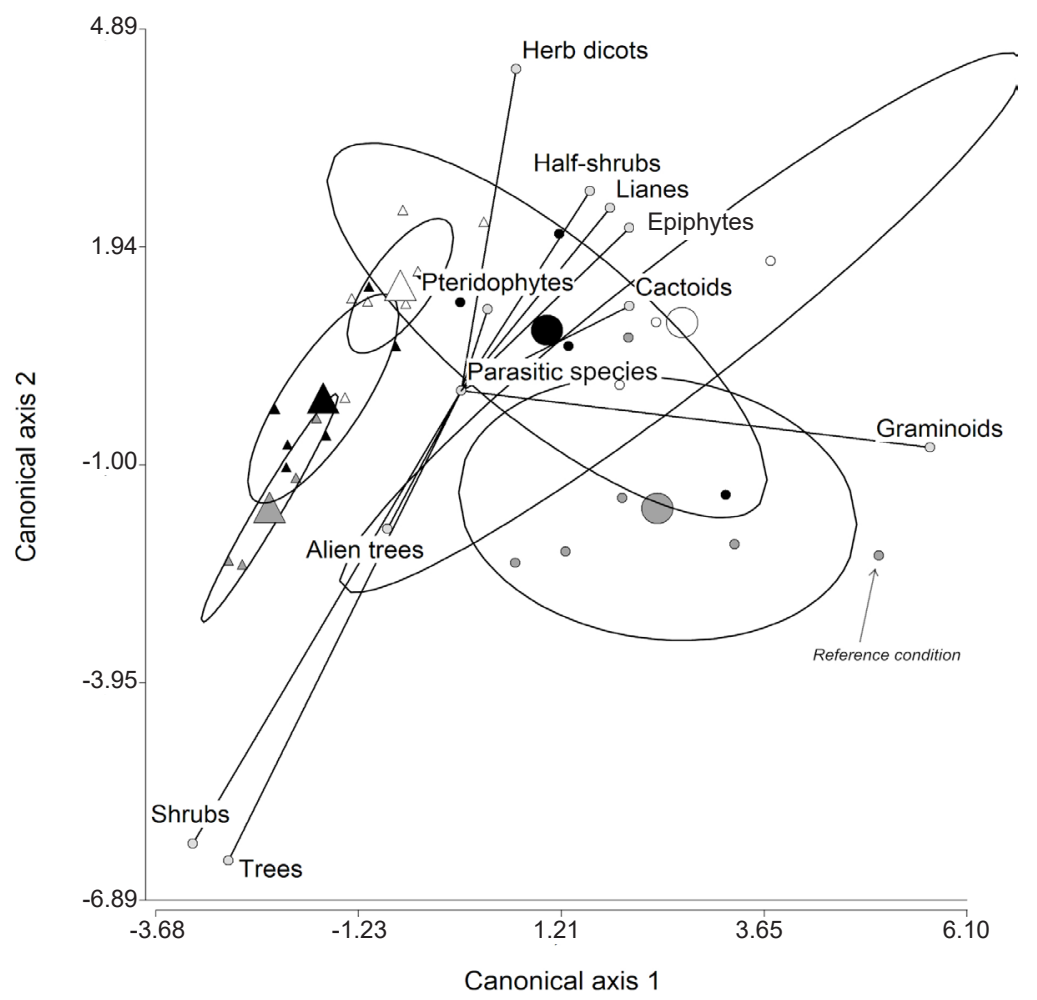

Fig. 4. Biplot of plant groups in the area of intrazonal soils.

Triangles: overgrazed plots; circles: undisturbed plots. Small symbols represent individual plots; large symbols represent the centroids of each treatment associated with their confidence ellipses. In white: 2012; in black: 2017; in gray: 2019. 
Table 1. Pearson`s correlation coefficients of functional plant groups, according to soil and disturbance categories

\begin{tabular}{|c|c|c|c|c|c|c|c|c|c|c|}
\hline $\begin{array}{l}\text { Functional } \\
\text { plant groups }\end{array}$ & 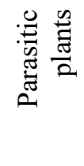 & 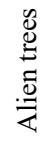 & $\frac{n}{\vec{E}}$ & $\begin{array}{l}\frac{n}{Z} \\
\frac{1}{ \pm} \\
\frac{1}{1} \\
\frac{\pi}{I}\end{array}$ & 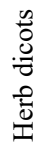 & 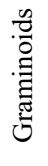 & 童 & 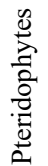 & 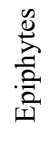 & 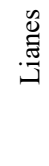 \\
\hline
\end{tabular}

\begin{tabular}{|c|c|c|c|c|c|c|c|c|c|c|}
\hline \multicolumn{11}{|c|}{ Azonal soils, undisturbed, $\mathrm{n}=51$} \\
\hline Alien trees & -0.07 & & & & & & & & & \\
\hline Shrubs & 0.13 & -0.03 & & & & & & & & \\
\hline Half-shrubs & 0.01 & 0.04 & -0.12 & & & & & & & \\
\hline Herb dicots & -0.09 & -0.14 & -0.19 & 0.19 & & & & & & \\
\hline Graminoids & -0.18 & 0.03 & $*_{-0.26}$ & $*_{-0.23}$ & $-2.90 \cdot 10^{-4}$ & & & & & \\
\hline Cactoids & 0.19 & -0.10 & -0.10 & -0.05 & -0.15 & -0.09 & & & & \\
\hline Pteridophytes & 0.13 & -0.09 & 0.16 & -0.02 & -0.18 & -0.17 & 0.40 & & & \\
\hline Epiphytes & -0.09 & 0.03 & -0.10 & $* * 0.34$ & 0.03 & -0.12 & 0.15 & 0.09 & & \\
\hline Lianes & -0.05 & -0.02 & 0.19 & -0.07 & $* * 0.32$ & -0.21 & -0.17 & -0.12 & -0.04 & \\
\hline Trees & -0.15 & -0.13 & -0.04 & 0.03 & -0.15 & -0.10 & $* * 0.32$ & $* * 0.29$ & 0.11 & -0.17 \\
\hline \multicolumn{11}{|c|}{ Azonal soils, disturbed, $\mathrm{n}=21$} \\
\hline Alien trees & 0.00 & & & & & & & & & \\
\hline Shrubs & 0.00 & -0.14 & & & & & & & & \\
\hline Half-shrubs & 0.00 & -0.28 & -0.20 & & & & & & & \\
\hline Herb dicots & 0.00 & $* 0.38$ & $* *-0.52$ & 0.06 & & & & & & \\
\hline Graminoids & 0.00 & 0.29 & -0.13 & -0.14 & 0.28 & & & & & \\
\hline Cactoids & 0.00 & -0.02 & 0.10 & -0.16 & -0.11 & -0.07 & & & & \\
\hline Pteridophytes & 0.00 & -0.11 & -0.10 & -0.14 & -0.12 & 0.10 & 0.15 & & & \\
\hline Epiphytes & 0.00 & -0.05 & $* 0.39$ & -0.18 & *_- 0.40 & -0.27 & -0.16 & -0.10 & & \\
\hline Lianes & 0.00 & 0.10 & 0.16 & 0.06 & -0.04 & 0.23 & -0.18 & -0.12 & 0.15 & \\
\hline Trees & 0.00 & -0.11 & 0.27 & 0.17 & -0.36 & -0.29 & 0.06 & -0.10 & $* * 0.47$ & 0.33 \\
\hline \multicolumn{11}{|c|}{ Intrazonal soils, undisturbed, $\mathrm{n}=14$} \\
\hline Alien trees & 0.00 & & & & & & & & & \\
\hline Shrubs & 0.00 & 0.15 & & & & & & & & \\
\hline Half-shrubs & 0.00 & -0.24 & 0.31 & & & & & & & \\
\hline Herb dicots & 0.00 & -0.10 & -0.06 & -0.23 & & & & & & \\
\hline Graminoids & 0.00 & -0.13 & 0.43 & 0.13 & -0.12 & & & & & \\
\hline Cactoids & 0.00 & -0.31 & 0.40 & $* * 0.66$ & -0.10 & -0.02 & & & & \\
\hline Pteridophytes & 0.00 & $* * 0.53$ & -0.21 & -0.25 & 0.41 & -0.15 & -0.04 & & & \\
\hline Epiphytes & 0.00 & 0.06 & -0.32 & -0.19 & -0.20 & $*-0.48$ & 0.20 & -0.13 & & \\
\hline Lianes & 0.00 & 0.44 & -0.30 & 0.02 & -0.31 & -0.06 & -0.28 & 0.18 & -0.03 & \\
\hline Trees & 0.00 & 0.22 & -0.42 & 0.24 & -0.02 & $-4.30 \cdot 10^{-3}$ & 0.30 & 0.52 & 0.05 & 0.40 \\
\hline \multicolumn{11}{|c|}{ Intrazonal soils, disturbed, $\mathrm{n}=19$} \\
\hline Alien trees & 0.00 & & & & & & & & & \\
\hline Shrubs & 0.00 & -0.12 & & & & & & & & \\
\hline Half-shrubs & 0.00 & -0.27 & 0.04 & & & & & & & \\
\hline Herb dicots & 0.00 & -0.13 & $* * 0.45$ & 0.16 & & & & & & \\
\hline Graminoids & 0.00 & $* 0.39$ & -0.22 & -0.17 & 0.25 & & & & & \\
\hline Cactoids & 0.00 & -0.30 & 0.31 & -0.14 & $* * 0.46$ & -0.09 & & & & \\
\hline Pteridophytes & 0.00 & 0.22 & 0.02 & -0.02 & 0.10 & -0.14 & -0.03 & & & \\
\hline Epiphytes & 0.00 & -0.17 & $* * 0.87$ & 0.19 & $* * 0.47$ & $*-0.39$ & 0.14 & 0.08 & & \\
\hline Lianes & 0.00 & -0.16 & -0.17 & 0.26 & -0.15 & -0.30 & 0.10 & 0.06 & $-2.20 \cdot 10^{-3}$ & \\
\hline Trees & 0.00 & -0.25 & 0.11 & 0.38 & 0.30 & $* *-0.46$ & 0.35 & 0.06 & 0.27 & 0.35 \\
\hline
\end{tabular}

$* p<0.1 ; * *<<0.05$. 
Each treatment creates different relationships between functional plant groups. In undisturbed plant communities located in the area of azonal soils, trees seem to facilitate the development of cactoids and pteridophytes. Halfshrubs are positively correlated with epiphytic species, and negatively correlated with graminoids. In disturbed plots, the occurrence of herbaceous dicots seems to be facilitated by the presence of alien trees and shrubs. Trees and shrubs are, as can be seen in the field, hosts of most of the epiphytic species. Since the occurrence of herbaceous dicots is positively related to shrubs, the occurrence of epiphytic species is also positively related to herbaceous dicots.

In undisturbed plant communities located in the area of intrazonal soils, half-shrubs are positively related to cactoids. Alien tree species seem to facilitate the appearance of pteridophytes. Graminoids and epiphytic species are negatively related. In disturbed plots, alien species facilitate the occurrence of graminoids, while shrubs facilitate the occurrence of herbaceous dicots and host epiphytic species. Since the occurrence of herbaceous dicots and epiphytic species is facilitated by the presence of shrubs, they are also positively linked. Trees seem to compete with graminoids significantly when plots are disturbed by overgrazing. On both disturbed and undisturbed plots, graminoids always correlated negatively with the rest of the functional plant groups.

\section{Successional pathways}

In Figs 5-6 the phase diagrams for plant communities located in the area of azonal and intrazonal soils, respectively, are shown. In each case, there is a bifurcation where plant ecological successions follow different pathways.

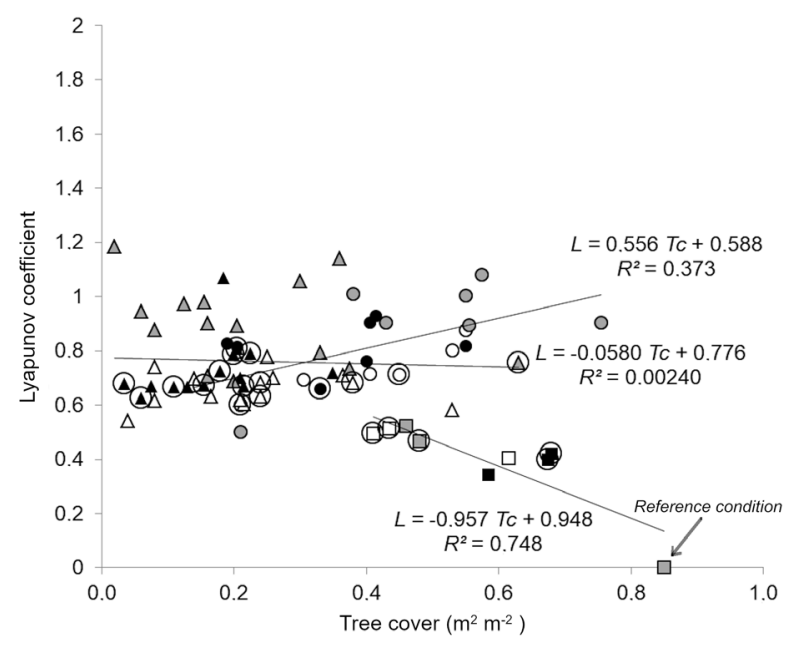

Fig. 5. Phase diagram for the plant communities in the area of azonal soils. In white: 2012; black: 2017; gray: 2019 .

Squares: Schinopsis lorentzii forests; circles: Vachellia spp. woodlands; triangles: grasslands/mixed woodlands.

Encircled symbols represent disturbed plots.

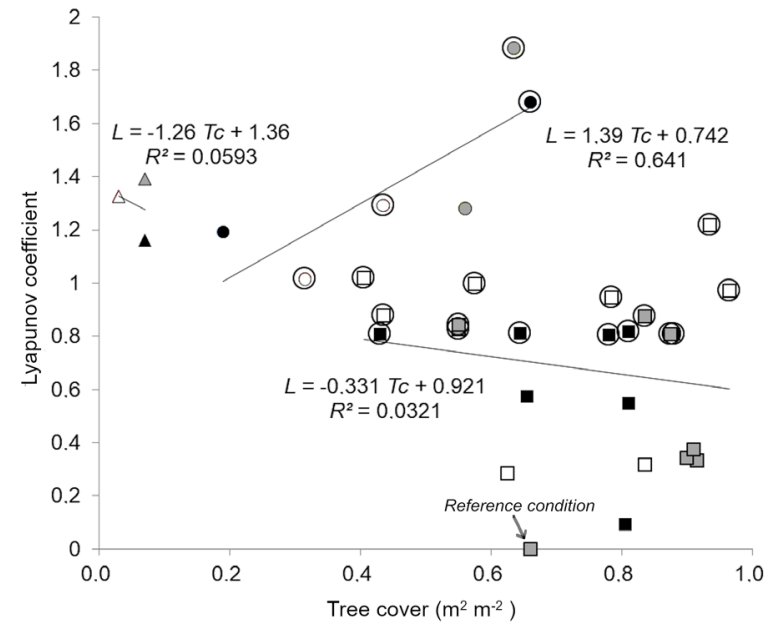

Fig. 6. Phase diagram for the plant communities in the area of intrazonal soils. In white: 2012; black: 2017; gray: 2019. Squares: Sebastiania commersioniana forests; circles: Lithraea molleoides forests; triangles: riparian grasslands. Encircled symbols indicate disturbed plots.

In the area of azonal soils (Fig. 5), the Schinopsis successional pathway reduces Lyapunov coefficients while tree cover increases, reaching the reference condition. The Vachellia successional pathway separates from the Schinopsis pathway, increasing Lyapunov coefficients while tree cover increases. Such a pathway seems to converge with the grassland/mixed woodlands pathway, suggesting that both might belong to the same succession. All three successional pathways start at the mid-position of the diagram, reflecting the 2012 conditions at $L$ values of about 0.6-0.7. The bifurcation of both successional pathways seems to occur at tree cover values of $0.4 \mathrm{~m}^{2}$ $\mathrm{m}^{-2}$.

In the second diagram (Fig. 6), a similar phenomenon occurs. Both Sebastiania and Lithraea successional pathways follow different directions; the first towards the reference condition, the second away from the reference condition. Again, the origin of both pathways seems to start at $L$ values of about $0.6-0.7$, and the 2012 conditions concentrate nearby these $L$ values. However, in this case, such concentration is more diffuse than in the area of azonal soils.

In both cases, the disturbed plots are closer to the centre of the figures, showing a retrogression along the succession.

\section{Discussion}

Both biplots and phase diagrams are useful to analyse disturbances within the plant successions. Rainfall, human-caused disturbances, and plant interactions are the leading causes explaining the changes in the relative cover of plant populations in the studied plant communities.

In undisturbed plant communities located in the area of azonal soils, the most evident change was that of the graminoids' cover. The 2019 increase might be 
due to the resprouting effect after 2017 fire events and to wetter conditions during 2018/19. The post-burned and overgrazing recovery resprouting during 2019 in ten of the disturbed plots was quite intense. It affected the average relative cover in graminoids in the azonal soils' plots. It is suggested that, under low severity wildfires, such as the one that occurred in 2017, graminoids might increase the post-fire biomass production by means of a reduced intra and interspecific competition (GiTTINs et al., 2011), reduced accumulation of dead biomass (MCCARRON and KNAPP, 2003), and by higher availability of soil nutrients (DENEGRI et al., 2014). The graminoid`s biomass production seems to be indifferent to the precipitation of previous years and holds a direct relation with the yearly SPI. The same effect was observed by FEBRUARY et al. (2013) in South African savannas.

In the area of azonal soils, shrubs and half-shrubs seem to compete with graminoids. The stress-gradient hypothesis suggests that under semiarid conditions as occurs in the study area, competition between shrubs and grasses might prevail instead of effects of facilitation (MAestre et al., 2009; Dohn et al., 2013). However, in plant communities located in the area of intrazonal soils, this effect does not occur since shrubs and half-shrubs are not the dominant functional groups and water is not the limiting resource.

In disturbed plant communities located in the area of azonal soils, the physiognomy drastically changes compared to undisturbed plots, especially by the effect of fire and overgrazing, dulling the climatic effect and altering the interaction between functional plant groups.

Plant communities significantly affected by grazing are also in the area of intrazonal soils. In $\mathrm{S}$, graminoids are mainly represented by the umbrophile species Oplismenus hirtellus (L.) P. Beauv. and they seem to be craved by cattle. During the surveys, it was quite evident that those plots excluded from livestock showed an increased cover of this grass, even under dense canopies of $S$. commersioniana. Grasses seem to be indifferent to tree shading in undisturbed plots, but become depleted when overgrazing occurs, apparently because such disturbance reduces the competitive ability of the species in the shade of trees against other functional groups of plants.

In the area of both soil types, pteridophytes increase their cover in disturbed places; they are mainly represented by Cheilanthes buchtienii (Rosenst.) R.M. Tryon and Anemia tomentosa (Savigny) Sw. GuO et al. (2003), ZHU et al. (2016) and SCHWARTSBURD (2017) suggest that some ferns have more significant growth rates and tend to occupy open areas in disturbed plots.

No evident successional pathways were identified by cover analysis of the functional plant groups. On the contrary, the phase diagrams enabled the identification of several successional pathways in the area of each soil type. The discrimination by physiognomic dissimilarity criteria of the surveyed plots showed two successional pathways in the plant communities located in the area of azonal soils and three in the area of intrazonal soils. In the first, G/MW and $\mathrm{V}$ communities seemed to have crossed ecological thresholds. Floristically, G/MW communities are very similar to V; however, they differ physiognomically in the Vachellia trees coverage. The Sc plant communities resulted to be floristically different from $\mathrm{V}$ and G/MW even though the herbaceous species in the understory are similar (GIORGIS et al., 2017). Such differences are marked, especially regarding the diversity of the tree functional group. In the $\mathrm{x}$-axis of the diagram (Fig. 5), V and Sc plant communities show similar tree cover. However, they differ importantly in the specific relative cover. Based on this fact, it can be stated that the G/MF and V communities do not evolve towards Sc physiognomy.

The impact of disturbances over these plant communities depends on their severity. Fire events reset the herbaceous functional groups and alter the rest of the functional groups. However, since wildfires are usually of low intensity $\left(100-200^{\circ} \mathrm{C}\right)$ (DENEGRI et al., 2014; KARLIN et al., 2016) woody plants and half shrubs can recover after the first rainfall events. Overgrazing disturbances will also depend on the loading of pasture with cattle and grazing intensity and frequency. Both disturbance types will retract the succession primarily reducing plant species cover, i.e. Lyapunov coefficients will increase with respect to the reference condition. If the disturbance severity is high, the coverage of trees may be drastically reduced, and it may trespass critical thresholds.

In the area of intrazonal soils, we have noticed that dissimilarity among communities might be due to a topographic limitation. The $\mathrm{R}$ areas usually hold low tree coverage, controlled by the flooding cycles and watertable depth. The S communities usually locate a step above riparian communities, apparently controlled by the watertable depth, but do not seem to be affected by periodic flooding. The Lm communities are usually mixed within an ecotonal sector with S communities, but they usually locate topographically above these communities. The Lm communities escape from the water-table influence. All three seem to be part of different ecological successions and can be modelled, as is shown in Fig 6 .

From the functional standpoint, $\mathrm{S}$ and $\mathrm{Lm}$ communities are intermixed (Fig. 4) and do not differ much in the cover of the functional plant groups. However, both communities can be differentiated floristically by analysing their dissimilarity. The R communities differ importantly both floristically and functionally; nevertheless, only one case was analysed for this study, and it should be more closely examined. In consequence, R, S and Lm communities follow different successional pathways.

Functionally, specific studies should be done to evaluate if the species of each functional group offers similar ecosystem services. Floristically, phase diagrams should be validated in each case to evaluate restoration and rehabilitation strategies. Knowing the disturbance history might help to reconstruct each successional pathway.

In the view of higher rainfall tendencies (Aliaga et al., 2016; CAmilloni, 2018), plant communities located in the area of azonal soils are expected to increase the cover of graminoids while reducing the cover of shrubs and half-shrubs. The increase in the graminoids' cover will depend mainly on grazing effects by livestock, affecting the severity, intensity and frequency of fire events. 
In the area of intrazonal soils, most of the functional plant groups are indifferent to rainfall. The constant expansion of alien tree species in these areas should be carefully studied in the future, by monitoring how they affect other functional plant groups, especially those controlling flood events.

\section{Acknowledgements}

The authors thank the AVINA Foundation for funding this research. Special thanks to Agustín Kruel, María Amalia Bernasconi, and Juan Nicolás Kruel for their support in the manuscript`s English correcting.

\section{References}

Aliaga, V.S., Ferrelli, F., Alberdi-Algarañaz, E. D., Bohn, V.Y., Piccolo, M.C., 2016. Distribución y variabilidad de la precipitación en la Región Pampeana, Argentina [Distribution and variability of the precipitation in the Pampean Region, Argentina]. Cuadernos de Investigación Geográfica, 42 (1): 261-280. https://doi. org/10.18172/cig.2867

Baldwin, M., KellogG, C.E., Thorp, J., 1938. Soil classification. In Hambridge, G. (ed.). Soils and men. Yearbook of Agriculture. Washington D.C.: U.S. Dept. of Agriculture, p. 979-1001.

Bernasconi Salazar, J., Karlin, M., Accietto, R., Schneider, C., Rufini, S., ArnulPhi, S., 2015. Modelos de estados y transiciones: bases para el manejo de la vegetación en la Reserva Natural de la Defensa La Calera, Córdoba, Argentina [States and transitions models: bases for the management of the vegetation in the Natural Reserve of the Defence La Calera, Córdoba]. In Martinez Carretero, E., Dalmasso, A. (eds). Restauración ecológica en la diagonal árida de la Argentina 2. Mendoza: CRICyT-CONICET, p. 3-20.

Braun-Blanquet, J., 1979. Fitosociología. Bases para el estudio de las comunidades vegetales [Phytosociology. Bases for the plant communities study]. Madrid: Ed. Blume. $820 \mathrm{p}$.

Camilloni, I., 2018. Argentina y el cambio climático [Argentina and the climate change]. Ciencia $e$ Investigación, 68 (5): 5-10.

Castoldi, E., Quintana, J.R., Mata, R.G., Molina, J.A., 2013. Early post-fire plant succession in slash-pile prescribed burns of a sub-Mediterranean managed forest. Plant Ecology and Evolution, 146 (3): 272-278. https:// doi.org/10.5091/plecevo.2013.848

Cicuzza, D., Krömer, T., Poulsen, A.D., Abrahamczyk, S., Delhotal, T., Piedra, H.M., Kessler, M., 2013. A transcontinental comparison of the diversity and composition of tropical forest understory herb assemblages. Biodiversity Conservation, 22 (3): 755-772. https://doi.org/10.1007/s10531-013-0447-y

Craig, R.K., Nagle, J.C., Pardy, B., Schmitz, O.J., Smith, W.K., Christensen JR., N.L., Neuman, J. (eds), 2012. Berkshire encyclopedia of sustainability 5/10: ecosystem management and sustainability. Vol. 5. Great Barrington (MA): Berkshire Publishing Group. 460 p.

Corenblit, D., Steiger, J., Gurnell, A.M., Naiman, R.J., 2009. Plants intertwine fluvial landform dynamics with ecological succession and natural selection: a niche construction perspective for riparian systems. Global Ecology and Biogeography, 18 (4): 507-520. https://doi. org/10.1111/j.1466-8238.2009.00461.x

DAVIDSON, D.W., 1993. The effects of herbivory and granivory on terrestrial plant succession. Oikos, 68 (1): 23-35. https://doi.org/10.2307/3545305

de Bello, F., Lavorel, S., Díaz, S., Harrington, R., Cornelissen, J.H., Bardgett, R.D., Berg, M.P., Cipriotti, P., Feld, C.K., Hering, D., et al., 2010. Towards an assessment of multiple ecosystem processes and services via functional traits. Biodiversity Conservation, 19 (10): 2873-2893. https://doi.org/10.1007/s10531-0109850-9

Denegri, A., Toranzo, L., Rubenacker, A., Campitelli, P., KarLIN, M.S., 2014. Efecto de los incendios forestales sobre las propiedades del suelo [Effect of wildfires over soil properties]. NEXO Agropecuario, 2 (1-2): 10-14.

Di Rienzo, J., Casanoves, F., González, L., Tablada, M., Robledo, C., Balzarini, M., 2019. Infostat. Statistical software. Córdoba: Universidad Nacional de Córdoba, Facultad de Ciencias Agropecuarias.

Dohn, J., Dembélé, F., Karembé, M., Moustakas, A., AmÉvor, K.A., HanAN, N.P., 2013. Tree effects on grass growth in savannas: competition, facilitation and the stress-gradient hypothesis. Journal of Ecology, 101 (1): 202-209. https://doi.org/10.1111/1365-2745.12010

Du RiEtz, G.E., 1931. Life-forms of terrestrial flowering plants, I. Acta Phytogeographica Suecica, 3. Uppsala: Almquist \& Wiksells boktryckeri. 96 p.

February, E.C., Higgins, S.I., Bond, W.J., Swemmer, L., 2013. Influence of competition and rainfall manipulation on the growth responses of savanna trees and grasses. Ecology, 94 (5): 1155-1164. https://doi.org/10.1890/120540.1

Giorgis, M.A., Cingolani, A.M., Gurvich, D.E., Tecco, P.A., Chiapella, J., Chiarini, F., Cabido, M., 2017. Changes in floristic composition and physiognomy are decoupled along elevation gradients in central Argentina. Applied Vegetation Science, 20 (4): 558-571. https://doi. org/10.1111/avsc. 12324

Gittins, C., Ghermandi, L., Bran, D., 2011. Studying the post-fire performance of tussock grasses in Patagonia: survival, biomass production and early competition. Journal of Arid Environments, 75 (11): 986-990. https:// doi.org/10.1016/j.jaridenv.2011.05.005

Guo, Q., Kato, M., Ricklefs, R.E., 2003. Life history, diversity and distribution: a study of Japanese pteridophytes. Ecography, 26 (2): 129-138. https://doi. org/10.1034/j.1600-0587.2003.03379.x

JørGensen, S.E., SvireZhev, Y.M., 2004. Towards a thermodynamic theory for ecological systems. Amsterdam: Elsevier Ltd. 380 p.

Justus, J., 2008. Ecological and Lyapunov stability. Philosophy of Science, 75: 421-436. https://doi. org/10.1086/595836 
Kardol, P., Martijn Bezemer, T., Van Der Putten, W.H., 2006. Temporal variation in plant-soil feedback controls succession. Ecology Letters, 9 (9): 1080-1088. https:// doi.org/10.1111/j.1461-0248.2006.00953.x

Karlin, M.S., Arnulphi, S., Alday, A., Bernasconi Salazar, J., Accietto, R., 2016. Revegetación postincendio en matorrales de Acacia spp. en las Sierras of Córdoba, Argentina Central [Post-fire revegetation in Acacia spp. shrublands in Sierras of Córdoba, Central Argentina]. Oecologia Australis, 20 (4): 464-476. https:// doi.org/10.4257/oeco.2016.2004.06

Karlin, M.S., Bachmeier, O.A., Dalmasso, A., Sayago, J.M., Sereno, R., 2011. Environmental dynamics in Salinas Grandes, Catamarca, Argentina. Arid Land Research and Management, 25 (4): 328-350. https://doi. org/10.1080/15324982.2011.602176

Karlin, M.S., Bernasconi Salazar, J., Cora, A., SÁnchez, S., Arnulphi, S., Accietto, R., 2019. Cambios en el uso del suelo: capacidad de infiltración en el centro de Córdoba (Argentina) [Changes in soil use: infiltration capacity in the center of Córdoba (Argentina)]. Ciencia del Suelo 37 (2): 196-208.

Karlin, M.S., Galán, R., Contreras, A., Zapata, R., Coirini, R., Ruiz Posse, E., 2013. Exergetic model of secondary successions for plant communities in Arid Chaco (Argentina). ISRN Biodiversity, 2013. https://doi. org $/ 10.1155 / 2013 / 945190$

Karlin, M.S., Ontibero, F., Arnulphi, S.A., Bernasconi Salazar, J., 2018. Caracterización edafológica de la Reserva Natural de la Defensa La Calera, Córdoba (Argentina) [Edaphic characterization of the Natural Reserve of the Defence La Calera, Córdoba (Argentina)]. Multequina, 27: 5-22.

Karlin, M.S., Schneider, C., Rufini, S., Bernasconi Salazar, J., Accietto, R., Karlin, U., Ferreyra, Y., 2014. Caracterización florística de la Reserva Natural Militar Estancia La Calera [Floristic characterization of the Natural Military Reserve Estancia La Calera]. Nature and Conservation, 7 (1): 6-18. https://doi.org/10.6008/ SPC2318-2881.2014.001.0001

Maestre, F.T., Callaway, R.M., Valladares, F., Lortie, C.J., 2009. Refining the stress-gradient hypothesis for competition and facilitation in plant communities. Journal of Ecology, 97 (2): 199-205. https://doi.org/10.1111/ j.1365-2745.2008.01476.x

McCARron, J.K., KnAPP, A.K., 2003. C3 shrub expansion in a $\mathrm{C} 4$ grassland: positive post-fire responses in resources and shoot growth. American Journal of Botany, 90 (10): 1496-1501. https://doi.org/10.3732/ajb.90.10.1496

Moravec, J., 1969. Succession of plant communities and soil development. Folia Geobotanica et Phytotaxonomica, 4 (2): 133-164. https://doi.org/10.1007/BF02854599

Naresh Kumar, M., Murthy, C.S., Sesha Sai, M.V.R., Roy, P.S., 2009. On the use of Standardised Precipitation Index (SPI) for drought intensity assessment. Meteorological Applications, 16 (3): 381-389. https://doi.org/10.1002/ met.136

Nuche, P., Alados, C.L., 2018. Shrub interactions drive vegetation succession of subalpine grasslands under two climatic conditions. Journal of Plant Ecology, 11(2): 297-307. https://doi.org/10.1093/jpe/rtx002

Schwartsburd, P.B., 2017. Flora of Espírito Santo: Dennstaedtiaceae. Rodriguésia, 68 (5): 1559-1575. https://doi.org/10.1590/2175-7860201768504

Torres, R.C., Giorgis, M.A., Trillo, C., Volkmann, L., Demaio, P., Heredia, J., Renison, D., 2014. Post-fire recovery occurs overwhelmingly by resprouting in the Chaco Serrano forest of Central Argentina. Austral Ecology, 39 (3): 346-354. https://doi.org/10.1111/ aec. 12084

Ulrich, W., Zaplata, M.K., Winter, S., Fischer, A., 2019. Directional changes of species spatial dispersion and realised environmental niches drive plant community assembly during early plant succession. Journal of Plant Ecology, 12 (3): 409-418. https://doi.org/10.1093/jpe/ rty 038

Wikum, D.A., Shanholtzer, G.F., 1978. Application of the Braun-Blanquet cover-abundance scale for vegetation analysis in land development studies. Environment Management, 2 (4): 323-329. https://doi.org/10.1007/ BF01866672

Zeballos, S.R., Giorgis, M.A., Cingolani, A.M., Cabido, M., Whitworth-Hulse, J.I., Gurvich, D.E., 2014. Do alien and native tree species from Central Argentina differ in their water transport strategy? Austral Ecology, 39 (8): 984-991. https://doi.org/10.1111/aec.12171

Zhu, S.D.., Li, R.H., Song, J., He, P.C., Liu, H., Berninger, F., YE, Q., 2016. Different leaf cost-benefit strategies of ferns distributed in contrasting light habitats of subtropical forests. Annals of Botany, 117 (3): 497-506. https://doi.org/10.1093/aob/mcv179

Received July 28, 2020 Accepted November 27, 2020 


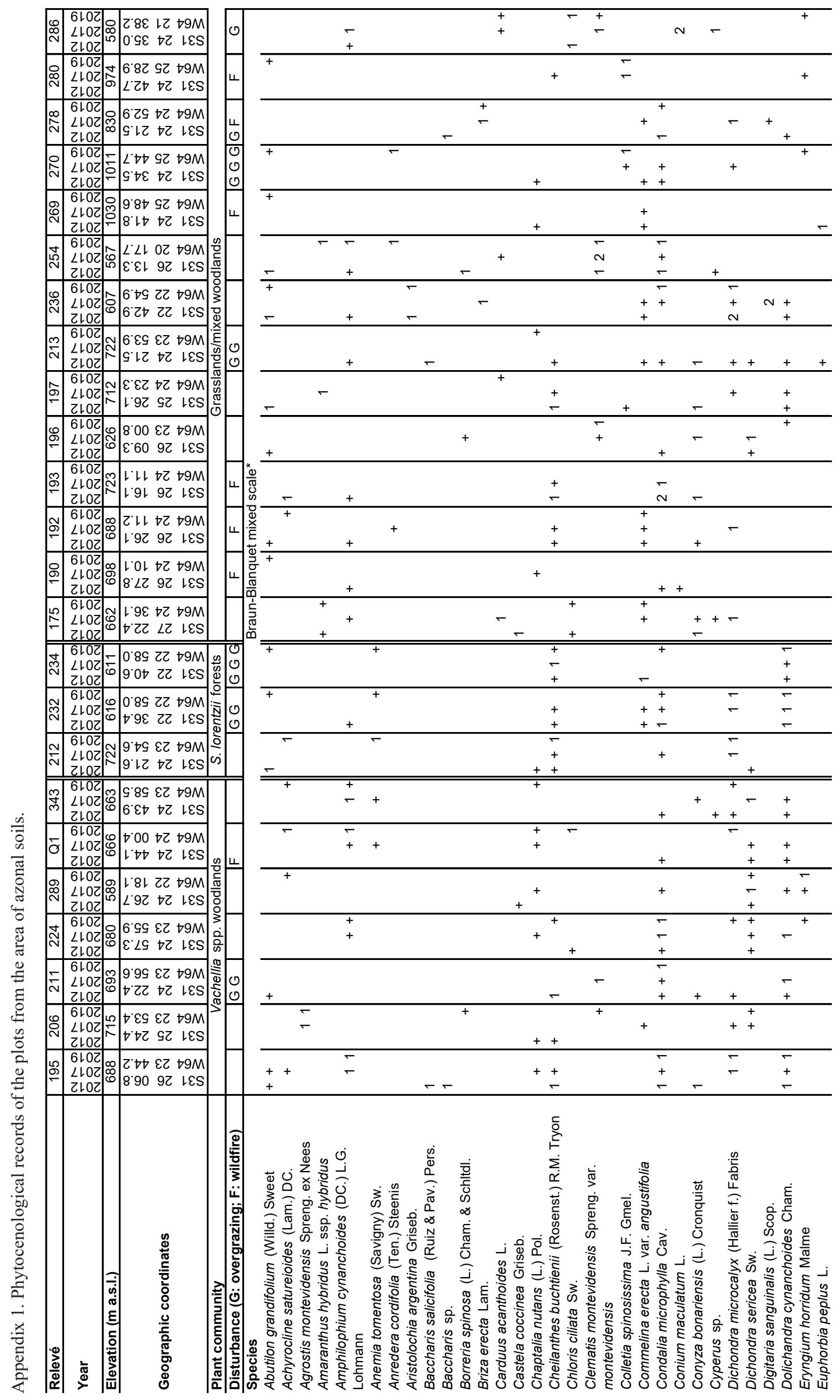




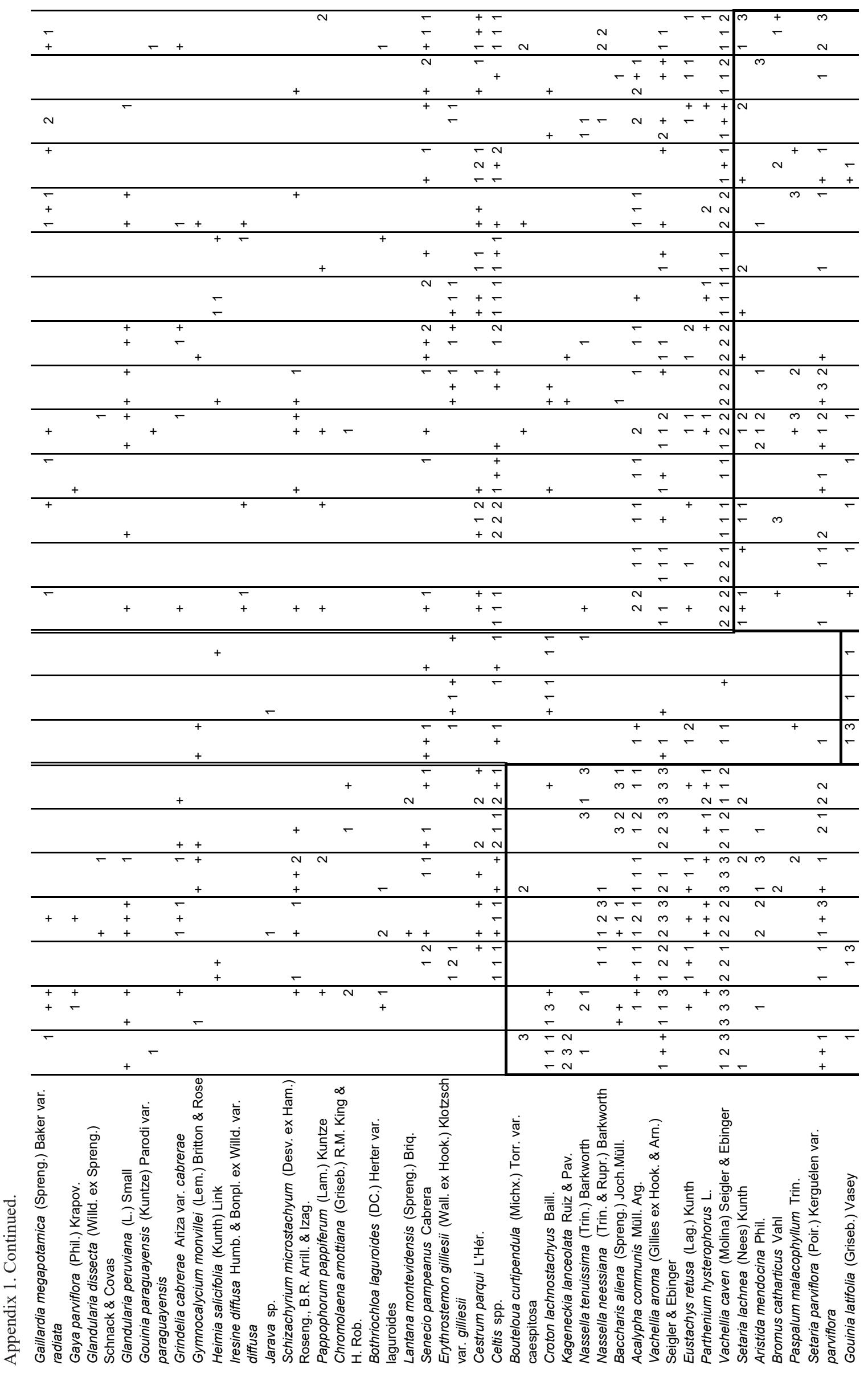




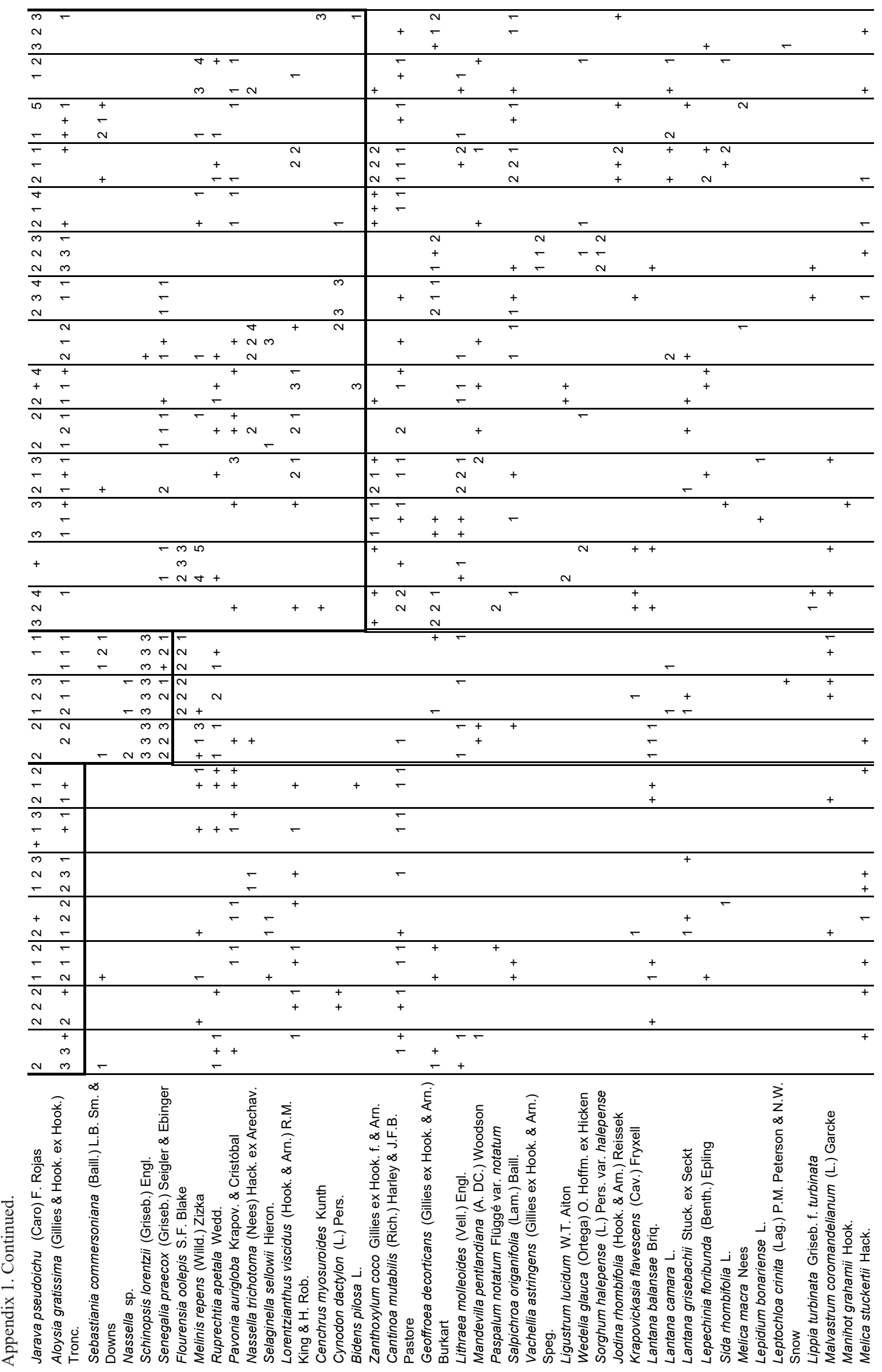




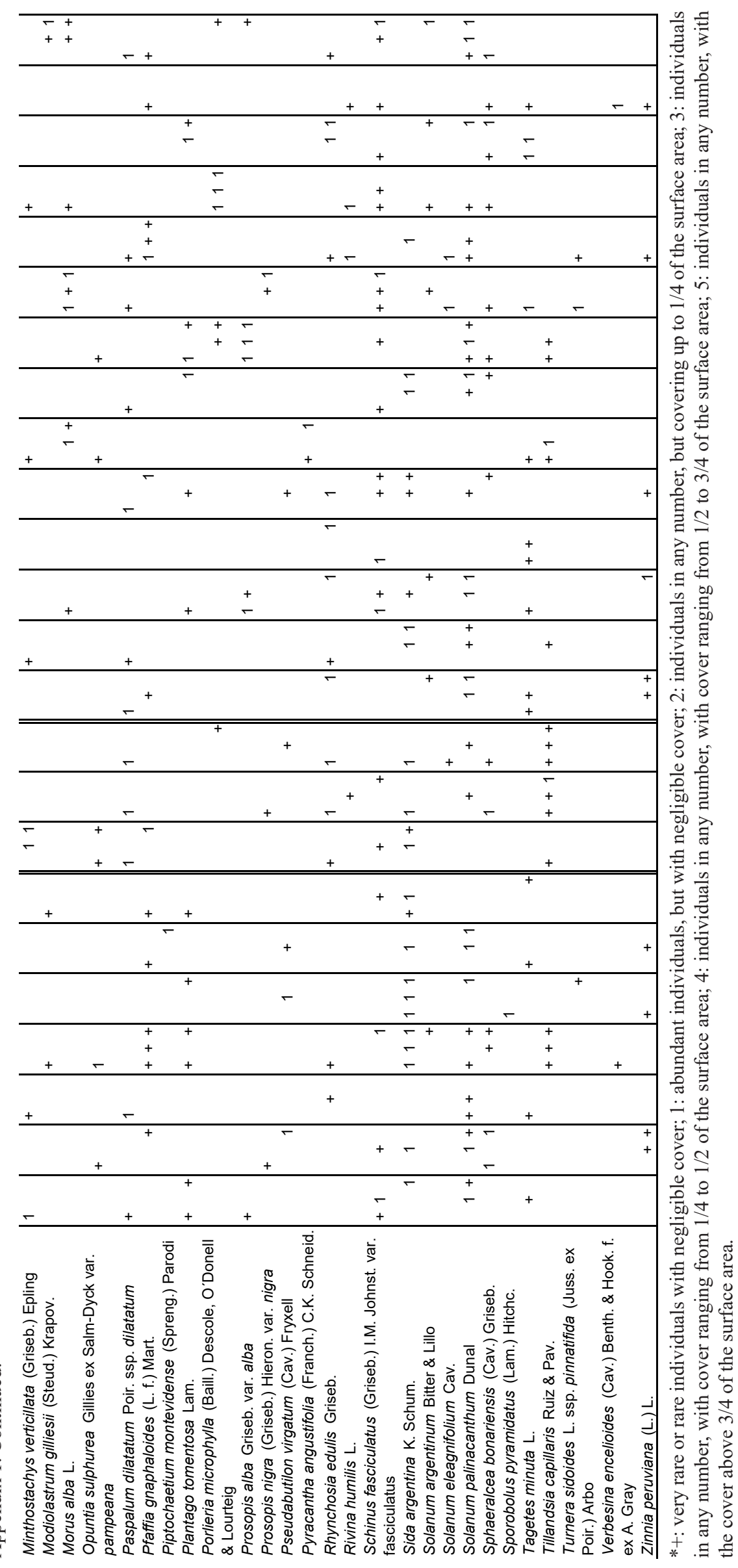


Appendix 2. Phytocenological records of the plots from the area of intrazonal soils.

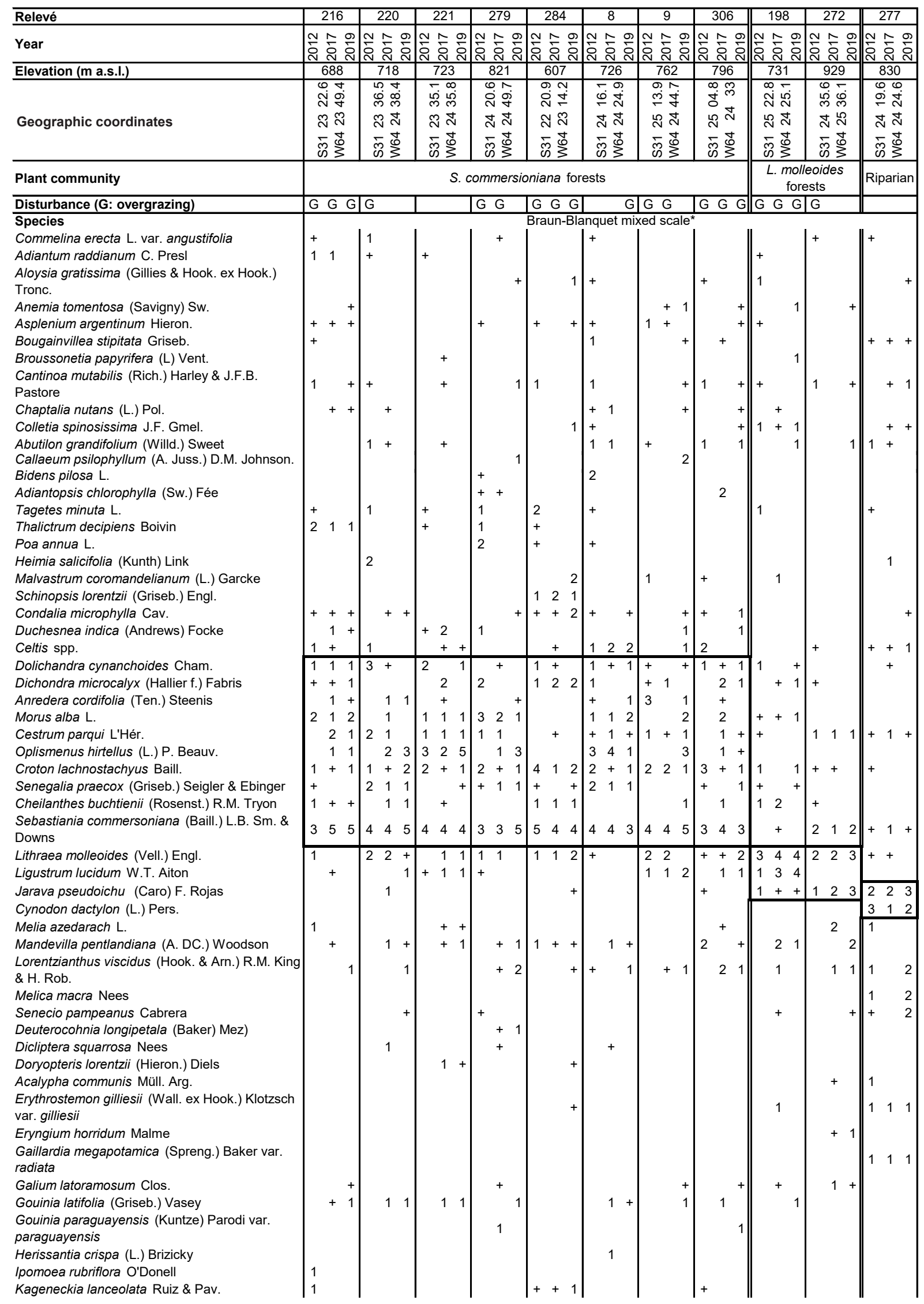


Appendix 2. Continued.

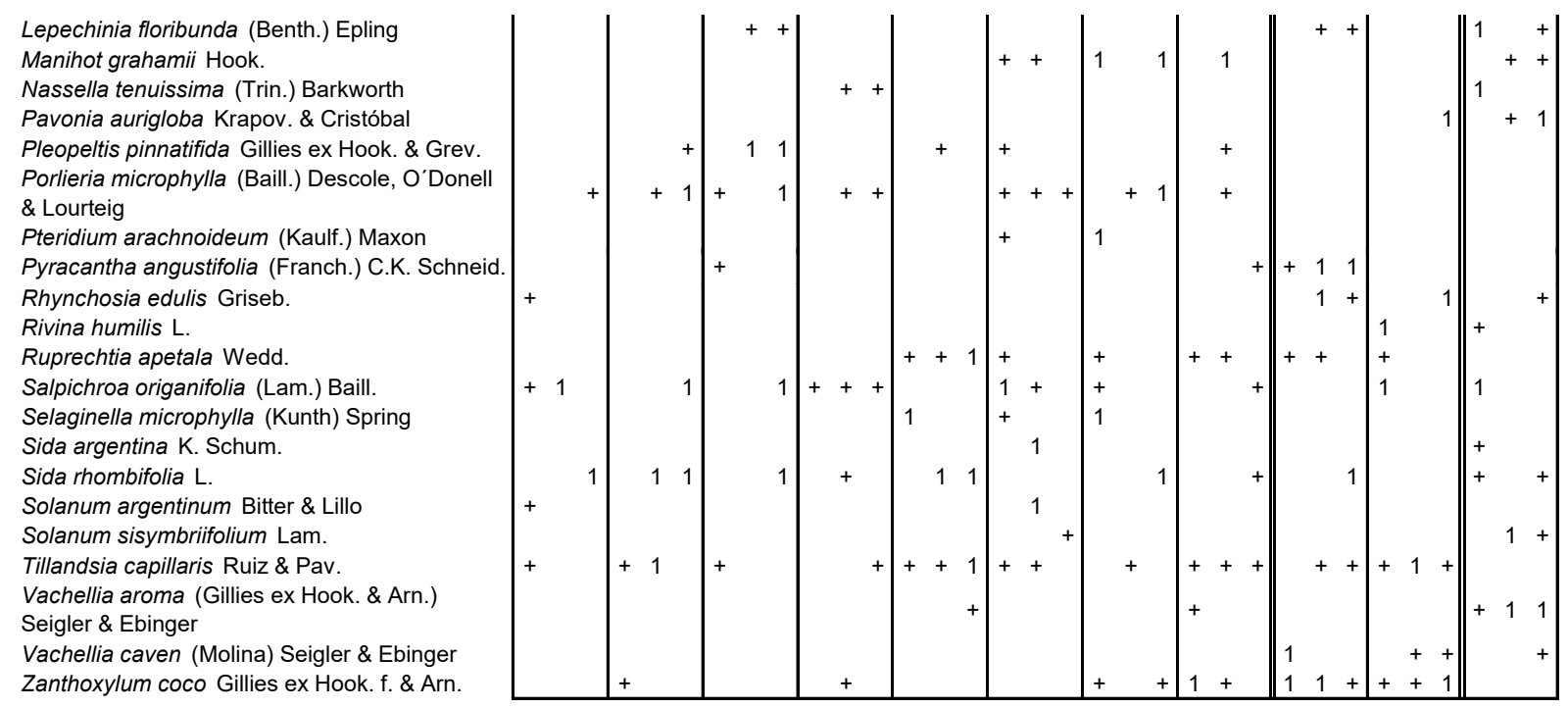
Zanthoxylum coco Gillies ex Hook. f. \& Arn.

*+: very rare or rare individuals with negligible cover; 1: abundant individuals, but with negligible cover; 2: individuals in any number, but covering up to $1 / 4$ of the surface area; 3 : individuals in any number, with cover ranging from $1 / 4$ to $1 / 2$ of the surface area; 4: individuals in any number, with cover ranging from $1 / 2$ to $3 / 4$ of the surface area; 5 : individuals in any number, with the cover above $3 / 4$ of the surface area. 